\title{
Crianças de Zuwara: imagens censuradas no Facebook
}

\author{
Bárbara Heller, Priscila Ferreira Perazzo \\ e Vinicius Guedes Pereira de Souza
}

\section{Resumo}

As imagens dos refugiados sírios povoaram as mídias em setembro de 2015. Enquanto a do menino Aylan Kurdi, morto em uma praia na Turquia, tornou-se meme, fotos de outras cinco crianças sem vida, também vítimas da guerra civil na Síria, foram censuradas no Facebook. Refletimos sobre as possibilidades que as imagens midiáticas tomam como "imagem intolerante" e imagem que se torna "engajada", ambas a serviço da política no mundo contemporâneo. Concluímos que as imagens das cinco crianças tornaram-se intolerantes por representarem 0 dissenso, aquilo que rompe com o senso comum que os meios de comunicação pretendem garantir entre emissores e receptores.

\section{Palavras-Chave}

Censura. Imagem intolerante. Facebook.

Bárbara Heller I b.heller@terra.com.br Doutora em Teoria Literária pela Universidade Estadual de Campinas, Brasil. Professora pesquisadora do Programa de Pós-Graduação em Comunicação da Universidade Paulista, Brasil.

Priscila Ferreira Perazzo | prisperazzo2@gmail.com Doutora em História pela Universidade de São Paulo, Brasil. Professora pesquisadora do Programa de Pós-Graduação em Comunicação da Universidade Municipal de São Caetano do Sul.

\section{Vinicius Guedes Pereira de Souza ।}

vgpsouza@uol.com.br

Doutor em Comunicação pela Universidade Paulista, Brasil. Professor do Centro de Estudos Latino-Americanos sobre Cultura e Comunicação da Universidade de São Paulo e do FIAM-FAAM Centro Universitário, Brasil.

\section{Introdução: o Problema}

Dois de setembro de 2015 talvez entre para a história do fotojornalismo como a data que trouxe aos olhos da população do planeta a saga de crianças vítimas da guerra civil na Síria, responsável pela expulsão de centenas de milhares de cidadãos nesse mesmo ano. Nilüfer Demir, fotógrafa profissional da agência de notícias Reuters, é a autora da imagem do menino sírio Aylan Kurdi, morto por afogamento, na beira do mar, em uma praia na Turquia. Sua história tornou-se tão conhecida quanto a fotografia de seu corpo estendido, de bruços, na areia: depois de a família ter sido impedida de imigrar para o Canadá, tentou cruzar o Mediterrâneo em direção à Europa, mas a viagem foi malsucedida. Sobreviveu apenas 0 pai, que decidiu voltar à Síria para enterrar seus mortos, apesar do visto de entrada e permanência que, finalmente, 0 Canadá lhe concedera devido à repercussão internacional do caso.

Em 29 de agosto, quatro dias antes de o Facebook, como tantos outros meios, divulgar esses fatos, sempre acompanhados pela imagem do menino 
Aylan, um de seus usuários, 0 artista plástico sírio

Khaled Barakeh, postou em sua página um álbum com sete fotografias, intitulado Multicultural

Graveyard $^{1}$, originalmente publicadas no blog da

ONG Migrant Report, no mesmo dia².

Seis delas são imagens de cinco crianças mortas, clicadas não se sabe se por voluntários do

Crescente Vermelho Líbio ou se por Mohammed Ben Khalifa, da Associated Press. Nas primeiras 24 horas, 0 álbum foi compartilhado por mais de 100.000 pessoas, entre elas, Nicholas D. Mirzoeff, docente da New York University3.
Sensibilizado pelas imagens, este professor divulgou as mesmas fotos em seu blog intitulado The Drowned and the Sacred ${ }^{4}$. Em 31 de agosto e também nos dias seguintes, foi informado por seus seguidores de que o link no Facebook para acessá-las não estava mais disponível, tampouco as do artista sírio. Sua reação foi tornar pública a notícia da eliminação do link, além de confirmar que o mesmo havia sucedido com 0 álbum de Khaled Barakeh.

Como não foi sequer notificado, o norte-americano pondera em sua página as razões que levaram 0 Facebook a tirá-los de circulação. Assim, infere que

Figura 1: Cinco crianças mortas em Zuwara, costa da Líbia, 2015
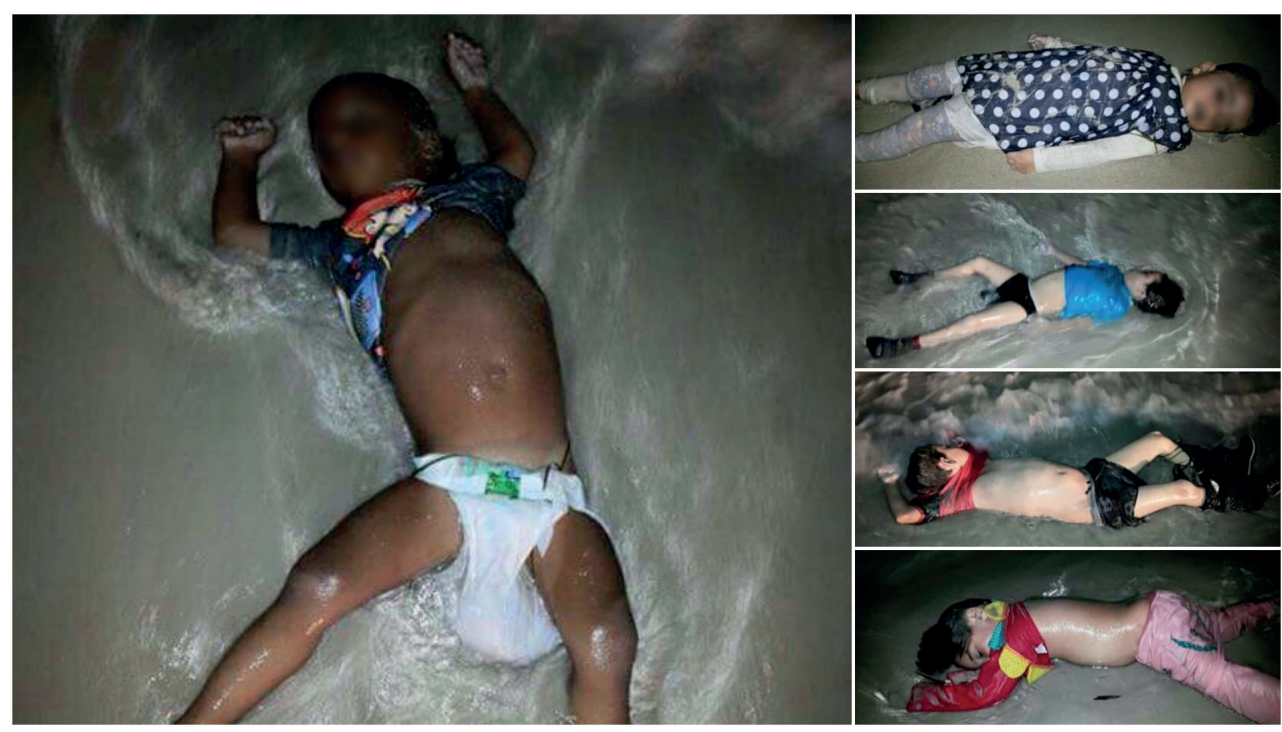

Fonte: Fotógrafos não creditados. Página da ONG Migrant Report. Corpos de crianças provavelmente sírias, afogadas, aparecem em praia da cidade de Zuwara (Líbia). Disponível em http://migrantreport.org/the-pictures-that-need-to-be-seen/ Acesso: 20 set. 2015.

Disponível em: https://www.facebook.com/khaledbarakeh/photos_albums Acesso: 22 out. 2015.

Disponível em: https://wp.nyu.edu/howtoseetheworld/2015/09/01/auto-draft-78/ Acesso: 22 out. 2015.

Disponível em: http://wp.nyu.edu/howtoseetheworld/2015/08/29/auto-draft-73/ Acesso: 20 out.2015.

Disponível em: http://wp.nyu.edu/howtoseetheworld/2015/08/29/auto-draft-73/. Acesso: 21/10/2015. 
pode ter alguma relação com a cláusula que consta na política de uso do Facebook, que ele reproduz: "Nós eliminamos imagens gráficas (graphic images) quando elas são compartilhadas para fins de prazer sádico ou para celebrar ou glorificar violência" .

Essas imagens, certamente, não correspondem a situações que insinuam sadismo. São imagens da violência, da atrocidade humana, mas não indicam sua celebração nem glorificação. Não há corpos mutilados, tampouco sangue ou incitação ao uso de armas. Trata-se de fotografias que revelam, sem nenhum disfarce ou tratamento estético, a crueldade das políticas contemporâneas que obrigam adultos e crianças a arriscarem suas vidas em travessias nada seguras, saindo do Oriente Médio e da África em direção à Europa.

Na versão em língua portuguesa dos "Termos de Serviço" do Facebook, o item 7 apresenta o seguinte texto, diverso do citado pelo norteamericano: "Você não publicará conteúdos que contenham discurso de ódio, sejam ameaçadores ou pornográficos; incitem violência; ou contenham nudez ou violência gratuita ou gráfica" ${ }^{\text {. }}$.

Embora os enunciados não sejam idênticos, 0 que sugere modulações do discurso do Facebook conforme os países em que se faz presente, a palavra "violência" comparece em ambas as versões. Restam, então, as perguntas: 0 que é considerado violência pelo Facebook? E o que pretendeu, afinal, essa rede social ao permitir a divulgação das imagens de Aylan Kurdi, na costa da Turquia, e reprimir as imagens de outras crianças sírias mortas na costa da África?

Violência é uma palavra de amplo espectro, a se deduzir do comportamento do próprio Facebook, uma vez que as mesmas imagens, postadas nas timelines dos autores deste artigo, em 5 de outubro de 2015 , não sofreram qualquer espécie de censura, nem no dia, nem nas semanas subsequentes. Ou seja: no Brasil, violência é compreendida ou tolerada de maneira diversa da dos países de língua inglesa? Nem mesmo nos comentários espontâneos de alguns dos seguidores houve menção à retirada destes conteúdos, apenas o choque emocional que elas provocaram, evidenciado nos comentários: "Eu vi [as imagens]. Queria desver"; "Não vi e queria não ter visto"; "Verdadeiramente horrível". Nota-se, também, o impacto da foto de Aylan Kurdi, que, embora tenha circulado posteriormente nas redes, ajudou a situar no tempo o momento em que as fotos das cinco crianças foram vistas: "Eu vi dois dias antes da imagem daquele bebê que foi mais divulgado"; "Vi logo antes daquela emblemática do menino que viralizou, tipo 1 dia antes". 
Outra hipótese para a permanência das imagens em nossas timelines baseia-se no que mencionou Nicholas D. Mirzoeff, em seu já citado blog: "[...] alguns [usuários] reportaram que as fotografias foram restituídas, devido à extensa indignação no próprio Facebook e no Twitter"?
Também é possível ponderar que as imagens anteriormente suprimidas foram liberadas depois de a foto de Aylan Kurdi ter circulado nas redes e se tornado um ícone ${ }^{8}$ pois representa, por semelhança, a crise dos refugiados sírios e palestinos. A partir dela, aceitam-se,

Figura 2: Comentários sobre as imagens das crianças mortas na timeline de um dos autores do artigo

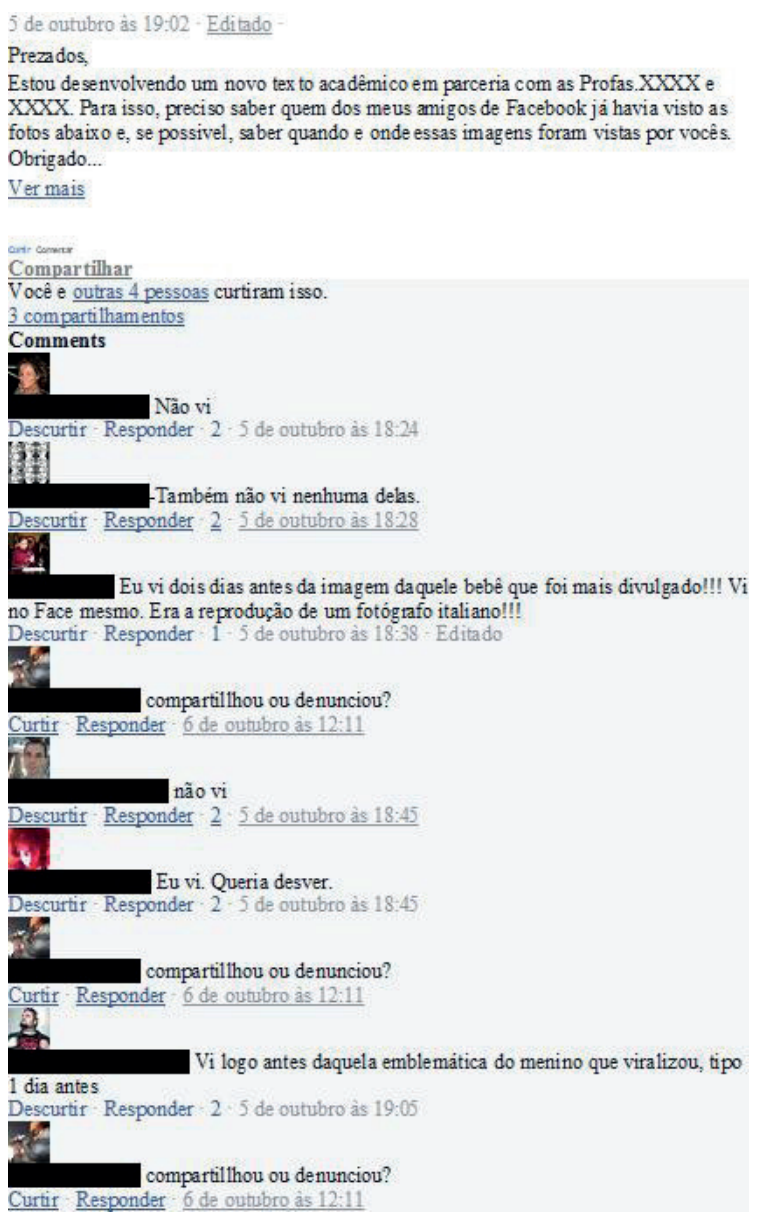

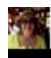

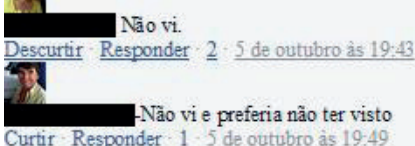

3.
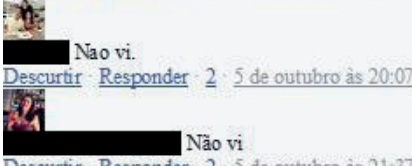

Descurtir - Responder 2.5 de outubro às $21: 37$
$\mathrm{Sim}$, ja havia visto. As imagens foram postadas por ocasião do afogamento do menino sirio de 3 anos por uma amiga inglesa. Verdadeiramente horrivel.

Descurtir Responder 2.5 de outubro as $22 \cdot 35$

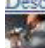

Ne compartillhou ou denunciou? Curtir-Responder - 6 de outubro as $12: 12$ Ver mais respostas
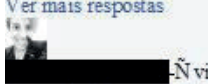

Descurtir Responder $2 \cdot 5$ de outubro às $22 \cdot 36$

(8)

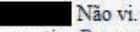

äo vi.

Descurtir Responder $2-2-5$ de outubro as $22: 46$

Fonte: Timeline de um dos atores do artigo no Facebook, 05/10/2015.

Texto original: "There is no justification in Facebook's own rubric for this arbitrary and unexplained action. It was applied inconsistently and some have since reported that the photographs have been restored, following extensive outrage on Facebook itself and Twitter." Disponível em: https://wp.nyu.edu/howtoseetheworld/2015/09/01/auto-draft-78/ Acesso: 22 out.2015.

8 Diversos autores tratam de categorias imagéticas que Charles Sanders Pierce chama de "índice", "ícone" e "símbolo". De forma simplificada, o índice é a categoria da identificação referencial, ou seja, a pessoa identifica na imagem o referente, o objeto fotografado. 0 ícone está ligado diretamente ao sensorial (emoção); é a primeira impressão, geralmente a mais marcante e muitas vezes a que perdura por mais tempo na memória. Já o símbolo traz uma carga de reflexão sobre os significados mais profundos de uma imagem, o que ela quer dizer de fato. 
supostamente, outras, menos "glamourizadas". Em outras palavras: é como se as imagens de Aylan provocassem a "desrealização" do mundo, ou seja, umas tornam as outras menos reais, banalizando a imagem, não mais provocando indignação.

Assim, posto o problema, os autores deste artigo pretendem refletir sobre as questões que envolvem a censura nos dias de hoje, a liberdade de expressão na rede social Facebook e as possibilidades que as imagens midiáticas tomam como "imagem intolerante" $\mathrm{e}$ imagem que se torna engajada ${ }^{10}$, ambas a serviço da política no mundo contemporâneo, a partir da expressão de fotos jornalísticas que circulam intensamente e, aparentemente livres, na internet.

\section{A força das imagens, a disputa da memória}

\section{Barbie Zelizer inicia seu livro Remembering to} forget $(1998$, p. 1) parafraseando Walter Benjamin, para quem imagens de eventos públicos do passado devem ser sempre mostradas para que funcionem como uma espécie de guia moral para o futuro. Com essa citação de Benjamin, a autora discute sobre as inúmeras e exaustivas fotografias tiradas nos campos de concentração nazistas europeus, tão logo foram libertados, sendo esse o seu objeto de estudo. Sua opinião, que dá continuidade à formulação do pensador alemão, é a de que os corpos dos mortos, assemelhandose a pilhas de palitos de fósforos nos visores das câmeras fotográficas, serviram, por um lado, para amortecer o senso crítico das gerações seguintes, mas, por outro, ajudaram a mostrar a crueldade e as atrocidades ali praticadas.

Nessa perspectiva, ambos os autores, em diferentes momentos de sua escritura, voltaram-se para a possibilidade de construções de memória, uma vez que as imagens que permanecem na lembrança, sejam "intolerantes" ou "engajadas", atuam como testemunhos de uma realidade, representam imagens do que se passou e reatualizam sentidos em torno dos acontecimentos.

Essa questão sobre o papel ou a função das imagens nos remete ao caso das crianças afogadas e deletadas do Facebook. Não se trata, convém explicar, de uma aproximação de eventos históricos tão distintos, como o Holocausto (1939-1945) e a crise enfrentada pelos refugiados sírios (2015). Mas, isso sim, de adaptarmos os questionamentos de Zelizer $(2008$, p. 1) sobre 0 uso das imagens para eventos contemporâneos. Nos perguntamos então: por quem e como foram feitas as sete primeiras imagens de crianças mortas em praia do norte da África? Em quais circunstâncias? Por que não repercutiram da mesma forma que as diversas imagens de Alyan Kurdi? Por que foram impedidas de circular no 
Facebook em um determinado momento? Que efeitos sociais e políticos elas estão provocando?

Não se sabe quem foi (foram) o(s) autor(es) das fotos que o Facebook censurou ou mesmo como foram realizadas. Podem ter sido tiradas pelos voluntários do Crescente Vermelho Líbio, os primeiros a chegarem à praia onde estavam esses corpos. Mas há, também, a hipótese levantada por Nicholas D. Mirzoeff, de que Khaled Barakeh as tenha editado a partir das imagens de Mohammed Ben Khalifa, da agência de notícias Associated Press. Não pretendemos aqui desvendar a autoria, mas analisar a maneira com que foram veiculadas. Inicialmente, como vítimas e mártires de regimes de exceção, portanto, como entes sagrados ou anjos, figuras além de plásticas, icônicas para as religiões cristãs. Mas, sem dúvida, como "imagens intolerantes", pouco palatáveis ao público e detentoras de domínios ideológicos por parte dos meios.

Infâncias subitamente interrompidas, em decorrência de uma longa guerra civil síria, reforçam essa associação de imagens. Não há, em nenhuma delas, recorrência a uniformes militares, armas ou expressões de ódio. Ao contrário: vestem roupas civis, coloridas. Uma delas ainda usa fraldas; sem a presença dos pais ou de outros adultos, a sensação de desamparo é enfatizada.

Mas essas crianças, apesar de tudo, não ganharam o mesmo espaço midiático da foto de
Aylan Kurdi, e Susan Sontag (2003, p. 61) fornecenos uma pista dos motivos:

Com relação aos nossos mortos, sempre vigorou uma posição enérgica contra mostrar o rosto descoberto. (...) Quando se trata dos outros, essa dignidade não é tida como necessária. Quanto mais remoto ou exótico o lugar, maior a probabilidade de termos imagens frontais completas dos mortos.

Zuwara, praia onde as crianças foram localizadas, fica a cerca de $60 \mathrm{~km}$ de Trípoli, capital da Líbia e, apesar da beleza idílica de sua paisagem, ganhou, nesse contexto, cores diferentes e negativas, reforçadas pela ausência da luz natural (são imagens noturnas) e pelo descuido da luz artificial (talvez impossível de se obter conforme se dera 0 registro fotojornalístico). Sua localização não europeia justifica considerá-la um lugar exótico e, portanto, sujeita à falta de cuidado sobre como é produzida e distribuída a imagem, como descreveu Sontag.

Também reconhecemos nas imagens aquilo que Roland Barthes (1990) considerou conteúdos denotativos (o que, efetivamente, "aparece" nas imagens) e conotativos (o que "parece" nas imagens), os quais, necessariamente, têm a ver com os contextos dos veículos e das sociedades em que as imagens são veiculadas. Nas palavras de Barbie Zelizer (2010, p. 5):

Por exemplo, na ainda ativa Guerra do Iraque, imagens de crianças proliferam de acordo com o contexto em sua volta: na imprensa de países 
responsáveis pela guerra, crianças são mostradas sendo ajudadas pelos militares, enquanto que na imprensa de países que se opõem à guerra, aparecem fotos de crianças mutiladas ou mortas. Denotativamente, podemos argumentar que ambos os conjuntos de imagens mostram a vida "como ela é", mas cada grupo faz mais sentido dentro de um contexto conotativo particular.

0 que "aparece" nas fotos das cinco crianças?

Três meninos e duas meninas mortos há pouco tempo, vestidos à moda ocidental e localizados à beira-mar, à noite, sozinhos.

0 que "parece" nas mesmas fotos? Cinco crianças inocentes, prematuramente mortas por afogamento e isoladas de um contexto maior: não vemos o barco que as levava, tampouco equipes de resgate ou outros cidadãos líbios consternados com a cena. Nem parentes, vivos ou mortos, chorando ou não, ao lado delas. As vítimas foram clicadas separadamente, como se jamais tivessem viajado juntas. E uma vez que suas identidades e respectivas idades não foram imediatamente reveladas, acentua-se a impressão de abandono e de estranhamento. São anônimos.

Note-se, também, que as imagens foram veiculadas nas redes sociais, caracterizadas por seu caráter interativo. Seus receptores são, também, coprodutores e transmissores, configurando uma circulação inimaginável antes do advento das mídias eletrônicas. Daí a importância do conceito "voz do visual", de autoria de Barbie Zelizer (2010, p. 13): "definida aqui como uma orientação da imagem para uma imaginação e emoção sugeridas por contingências de seu ambiente que facilitam sua relação com uma grande variedade de contextos, eventos, pessoas, práticas e outras imagens". Ou seja, as imagens ganham voz e contam mais que seus sentidos conotativos e denotativos. Dizem mais que meros registros. São relatos que ganham novos conteúdos advindos da imaginação, da emoção, da ideologia.

Sendo assim, compreende-se mais facilmente por que as fotos das cinco crianças afogadas ganharam súbita notoriedade para, na sequência, serem retiradas de circulação e entrarem em declínio, após o advento da imagem de Aylan Kurdi, transformada em "imagem-ícone" da maior crise de refugiados na Europa desde o final da Segunda Guerra Mundial.

Tirada por uma fotógrafa profissional em uma praia "europeia" e não em uma africana, já faz da foto de Aylan uma imagem dos "nossos mortos" (Sontag, 2003, p. 61). Além disso, por trabalhar para uma das maiores agências de notícias do mundo, a Reuters, essa foto ganhou "confiabilidade", não só pelo peso político e econômico da empresa no mundo corporativo da comunicação, com imensa capacidade de distribuição mundial de conteúdos, como também por corresponder às regras volúveis, mas nem tanto, da indústria midiática.

Não se vê na foto o rosto do menino. Como foi tirada à luz do dia, é menos sombria e menos impactante. Ainda totalmente vestido, inclusive 
Figura 3: Foto de Aylan Kurdi veiculada pela agência Reuters

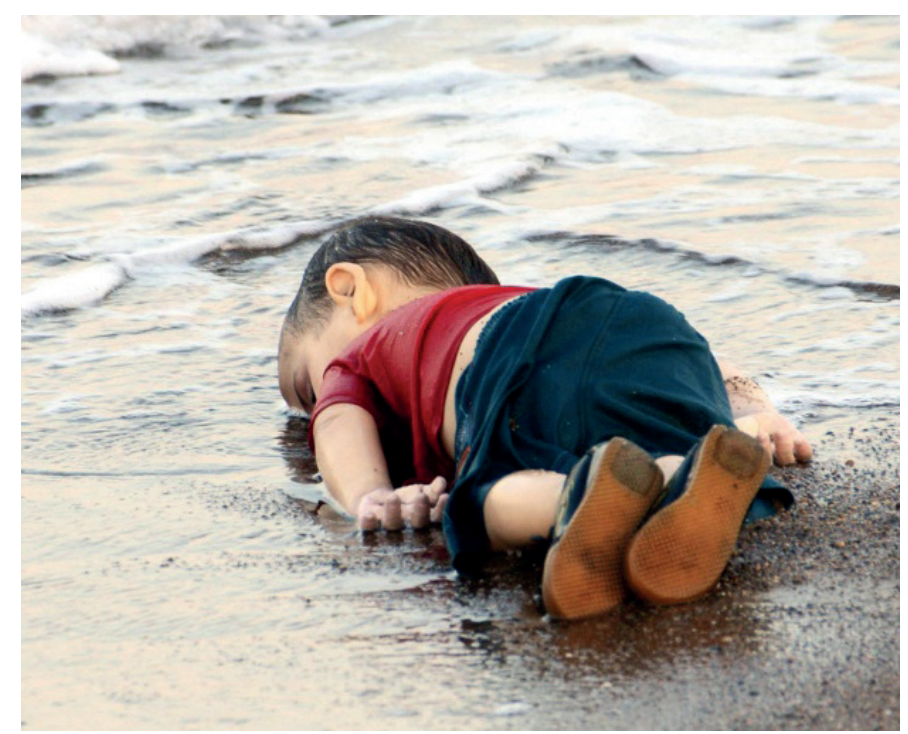

Fonte: http://static.reuters.com/resources/media/global/assets/ images/20150903/20150902_163244720150903003956.jpg

com seus sapatos, causa comoção imediata, pois logo se nota que era uma criança bem cuidada e que sua morte foi um trágico acidente.

Com a interação cada vez mais acentuada nas redes sociais como formas de comunicação interpessoal, acrescida à facilidade de se apropriar, modificar e retransmitir fotografias, a foto de Aylan Kurdi rompeu os meios tradicionais de comunicação e tornou-se onipresente nas telas de celulares, computadores, tablets e também na mídia impressa. Além disso, ela ainda apresenta o que Barthes (1984) chama de studium, ou seja, as técnicas de enquadramento, composição, iluminação e conotação de uma "boa" fotografia profissional, e não um simples clique de um amador.
Com uma estética mais acurada, cuidadosa e de acordo com os sentidos conotativos dos meios que a produziram e distribuíram, a foto de Nilüfer Demir pode ser entendida como uma imagem-ícone e considerada "arte engajada", diante de uma perspectiva ideológica.

Segundo Vinicius Guedes Pereira de Souza (2015, p.12),

Na internet e principalmente nas redes sociais, a fotografia original de Kurdi feita por Nilüfer Demir, e algumas de suas variações, imediatamente se multiplicou sob a hashtag \#KiyiyaVuranInsanlik (algo como "a humanidade levada pelas ondas", em turco) já na maioria das vezes omitindo o nome da fotógrafa, ou seja, com 0 usuário se apropriando da imagem. Fora da Turquia, mudaram as hashtags para expressões 
na língua de cada país por iniciativa própria dos usuários ou estimulados por meios de comunicação como o próprio The Independent, que pedia 0 envio de fotos dos leitores com cartazes dizendo \#RefuggesWelcome e solicitando assinaturas em uma petição do jornal ao governo para que aceite um número justo de refugiados. Logo em seguida, surgiram os memes, alterações na imagem original, principalmente associando a fotografia a outras imagens icônicas de conflitos.

Graças às possibilidades de manipulação das imagens, 0 descrédito de que elas estão contando uma verdade ou representando um evento, especialmente se não foi por nós experimentado, tem sido cada vez mais aguçado (Zelizer, 1998, p.2). Sendo assim, não há mais garantia de que uma memória coletiva esteja sendo preservada, apesar da onipresença da mídia, tida e havida como formadora de opiniões.

Quando a censura também entra em ação, não apenas transformando, mas eliminando imagens e/ou informações, as gerações seguintes aos eventos precisam recorrer aos depoimentos de testemunhas que, acionadas por suas memórias individuais, recuperam suas histórias e as relatam conforme seu estado emocional.

Isso posto, fica clara a grave intervenção do Facebook ao deletar os links já mencionados: no lugar de preservar para a memória coletiva as imagens mais críveis da crueldade da guerra civil, sem trabalho de luz ou de enquadramento, fixaram-se nas mentes e nos corações dos milhões de seus usuários a triste e sofisticada foto de Aylan Kurdi e seus memes. Dessa maneira, a liberdade de expressão foi comprometida, 0 esquecimento de que outras crianças mortas têm identidade própria foi acionado, e a memória coletiva foi construída ao dispor das regras e dos interesses dos representantes de meios como 0 Facebook. Isso nos permite dizer que as novas mídias digitais, nos dias de hoje, continuam por não permitir "imagens intoleráveis".

\section{"Imagens intoleráveis": política e censura}

Se tivesse sido o ditador da Síria, Bashar al-Assad, 0 agente da censura aos blogs já citados, talvez este artigo não fizesse sentido algum. No entanto, por se tratar de um cerceamento à liberdade de expressão por uma empresa de matriz estadunidense e utilizada por milhões de pessoas em todo o planeta, a reflexão se faz necessária mais uma vez.

Na sua "Declaração de Direitos e

Responsabilidades", encontra-se a seguinte norma: "Nós podemos remover qualquer conteúdo ou informação publicada por você no Facebook se julgarmos que isso viola esta declaração ou nossas políticas" ${ }^{\prime 2}$. Não ficam claros quais conteúdos ferem esses princípios, mas já é de conhecimento público que mamilos femininos e corpos nus, mesmo de civilizações que nunca usaram 
roupas, são retirados da rede. Mas, em outras circunstâncias, como sugere Antonio Martins, em matéria publicada no blog Outras Palavras, sediado no portal da revista CartaCapital em 18 de setembro de 2015, o Facebook parece optar por um controle mais difuso: "Ao invés de excluir, escolhe os conteúdos que chegarão a seus leitores. Afirma fazê-lo por meio de algoritmos 'neutros', mas se recusa a revelar que critérios orientam tais instruções - evidentemente construídas por seres humanos" (Martins, 2015, p. s/n) ${ }^{13}$.

Ainda segundo esse autor, podemos estar diante de algo mais grave: a censura política no Facebook, graças à retirada do ar de texto de Patrick Cockburn, "um dos maiores especialistas em Oriente Médio", que responsabiliza os EUA na origem da onda de refugiados que chega à Europa. Não houve qualquer justificativa da empresa, nem mesmo quando foi contestada, apenas a publicação do seguinte texto-padrão: "Esta mensagem contém conteúdo que foi bloqueado pelos nossos sistemas de segurança".

Esse caso é bastante similar ao corte dos links já citados, tendo em vista que as fotos das crianças afogadas na praia líbia colaboram, ainda que indiretamente, para a ideia de uma guerra civil e cruel, que tem como um dos seus agentes o país matriz do Facebook.
Essa é ainda uma resposta provisória e subliminar para os motivos que levaram o Facebook a censurar as cinco imagens. Lembremos das outras hipóteses já cogitadas em nosso artigo: indefinição da autoria, ausência de informações sobre suas eventuais relações com agências internacionais de notícias, "crueldade" das imagens.

Se a censura, como estamos concluindo, é política e, agora realçamos, também estética, o que torna as imagens políticas e estéticas?

Para Jacques Rancière, filósofo francês, há uma relação indissociável entre política e estética, como explica em entrevista que concedeu à Revista Cult (2009, p. s/n): "A estética e a política são maneiras de organizar o sensível: de dar a entender, de dar a ver, de construir a visibilidade e a inteligibilidade dos acontecimentos"14.

Para ele, a "política das imagens" acontece apenas quando se elimina o "continuum" entre 0 intuito do artista e a interpretação do receptor, isto é, quando ocorre um intervalo entre a produção da arte e 0 momento em que o receptor entra em contato com ela. Ângela Marques (2014, p. 64) também explica:

0 artista não tem controle sobre os efeitos e apropriações de sua arte, ele não pode afirmar, com certeza, que ela é política, afinal isso diz de uma interpretação livre do espectador. Sendo

13 MARTINS, Antonio. Censura política no Facebook? CartaCapital, São Paulo, 18/09/2015. Disponível em: http://www. cartacapital.com.br/blogs/outras-palavras/censura-politica-no-facebook-554.html Acesso: 23 out. 2015.

14 LONGMAN, Gabriela; VIANA, Diego. Entrevista com Jacques Rancière, concedida à Revista Cult, Edição nº 139, setembro de 2009. Disponível em: http://revistacult.uol.com.br/home/2010/03/entrevista-jacques-ranciere/ Acesso: 24 out. 2015. 
assim, é preciso que haja um intervalo entre a arte e o modo como o sujeito entra em contato com ela, um livre jogo no qual a arte não solicita nada do espectador e o espectador não deve produzir nenhuma ação sob os pretensos ditames da arte.

Não se trata mais da ideia platônica de mimese, isto é, da imagem como cópia ou representação do real ou a de que 0 autor irá provocar uma mudança repentina no receptor, mas "na suspensão de toda relação determinável entre a intenção da produção e efeito na recepção" (Ramos, 2012, p.103). É nesse hiato que se manifesta a politicidade da arte, quando há um dissenso entre a produção artística e fins sociais definidos, isto é, quando os modos de fazer, de dizer e de visibilidade são rompidos. Vê-se, assim, que a politicidade da arte diferencia-se da arte engajada, entendida, neste artigo, como a que é produzida intencionalmente para mobilizar os receptores, a fim de que defendam ou combatam uma causa.

0 conceito de "imagem intolerável" de Rancière (2012, p.84) também é fundamental para entendermos a filosofia que está propondo em seu capítulo homônimo. Entre vários exemplos, 0 autor cita a série Bringing the war, de Martha Rosler:

[...] sobretudo aquela colagem que nos mostrava, no meio de um apartamento claro e espaçoso, um vietnamita com uma criança morta nos braços. A criança morta era a intolerável realidade oculta pela confortável vida americana, a intolerável realidade que ela se esforçava por não ver e que a montagem política Ihe lançava no rosto.[...] Não haveria então nenhuma intolerável realidade que a imagem pudesse opor ao prestígio das aparências, mas um único e mesmo fluxo de imagens, um único e mesmo regime de exibição universal, e é esse regime que constituiria hoje 0 intolerável.

Quando comenta sobre a modelo nua e anoréxica em um desfile de modas em Milão, fotografada por Oliviero Toscani, Rancière conclui que, embora tenha causado impacto, não foi intolerável, uma vez que foi mostrada "sob o mesmo regime de visibilidade daquela realidade, que exibe alternadamente sua face de aparência brilhante e seu avesso de verdade sórdida que compõem um único e mesmo espetáculo" (Rancière, 2012 a, p. 84). Seguindo essa lógica, podemos compreender por que cenas impactantes, como tragédias e genocídios, quando publicadas em um jornal, não geram necessariamente efeito de indignação. Isso ocorre porque, muitas vezes, estão ao lado de notícias e cenas banais e acabam por se inserir em um mesmo fluxo de imagens do cotidiano.

Embora não chegue a uma conclusão sobre as condições que geram uma "imagem intolerável", Rancière propõe que são imagens da arte. Elas não fornecem armas de combate, mas contribuem para "desenhar configurações novas do visível, do dizível e do pensável e, por isso mesmo, uma paisagem nova do possível" (2012a, p. 100).

A foto de Sophie Riestelhueber, de 2005, comentada por Rancière, é exemplar: no lugar de clicar o muro que separa israelenses de palestinos, a fotógrafa optou por um conjunto de pedras em uma estrada, em uma paisagem mediterrânea. 0 filósofo pondera: "[Sophie Riestelhueber] 
não fotografou 0 emblema da guerra, mas as feridas e as cicatrizes que ela deixa no território" (Rancière, 2012a, p. 101).

Rancière (2012a, p. 99) ainda explica que

0 tratamento do intolerável é, assim, uma questão de dispositivo de visibilidade. Aquilo que chamamos imagem é um elemento num dispositivo que cria certo senso de realidade, certo senso comum. Um "senso comum" é, acima de tudo, uma comunidade de coisas sensíveis: coisas cuja visibilidade considera-se partilhável por todos.

E propõe que é necessário "construir outras realidades, outras formas de senso comum, ou seja, outros dispositivos espaçotemporais [sic], outras comunidades de palavras e coisas, formas e significados" (Rancière, 2012a, p. 99).

Ramos (2012, p. 103), ao comentar outra obra de Rancière, $O$ mestre ignorante (2002), retoma a ideia de que, quando um artista quer passar, intencionalmente, uma mensagem política, a arte engajada infantiliza o espectador. Daí a importância de combater a mimese e colocar no seu lugar o que Rancière chama de eficácia estética: a descontinuidade entre as formas sensíveis do artista e dos que recebem sua obra. Em outras palavras: a "suspensão de toda relação determinável entre a intenção da produção e efeito na recepção" (Ramos, 2012, p. 103).

É dessa maneira que podemos observar tanto a foto de Aylan Kurdi quanto as cinco fotografias das crianças na praia da Líbia. A primeira, como arte engajada, infantilizou o espectador, 0 qual se desapropriou de seu olhar político para denotar seus sentimentos de tristeza quanto ao fato ocorrido. Não são estranhos, portanto, os desdobramentos dessa imagem em uma série de desenhos publicados em seguida. Por sua vez, as fotografias das cinco crianças, publicadas juntas, sem um tratamento estético ideologicamente produzido pelos seus emissores, vêm ao encontro do pensamento de Rancière (2012a) que considera importante combater a mimese para que se crie essa descontinuidade entre 0 autor e 0 receptor da obra e, assim, possibilite gerar o dissenso, a interrupção, a discordância com 0 tácito, este gerado pela foto engajada do menino Aylan. Podemos ponderar, então, que as fotos da praia na Líbia são "imagens intolerantes" ou, ao menos, deveriam ser, no sentido de não tolerarmos as atrocidades, de não nos acostumarmos com 0 consenso.

Outros dois conceitos de Rancière, trabalhados em $O$ destino das imagens (2012b), também nos ajudam a refletir sobre as fotografias das cinco crianças deletadas do Facebook. A imagem deve ser compreendida em sua alteridade, o que significa não reduzi-la à mera expressão do que se vê. Segundo Hussak Ramos (2012, p. 104), "a imagem, ao contrário do que possa parecer à primeira vista, não se reduz ao que ela possui de visual, pois nela operam também o não-visível, o dizível e 0 indizível", como nos apresentou, anteriormente, Roland Barthes (1990) sob os conceitos de conotação e denotação. 
Dessa ideia, advém outro conceito de Rancière (2012b): o caráter paradoxal da imagem, que, por um lado, é autônoma, pode dizer algo por si só; e, por outro, é parte de um discurso, é um dos elementos da composição do fluxo imagético e, nesse sentido, não tem autonomia para "falar sozinha" (Rancière, apud Ramos, 2012, p. 104).

Parecem ser bastante próximas as noções de alteridade de Rancière e de conotação de Barthes, já analisadas neste artigo: os corpos das crianças sugerem, pela alteridade ou pela conotação, a atrocidade da guerra civil, embora não conste nas imagens a paisagem de um lugar desolado pela violência. Há apenas espuma do final das ondas em uma praia, as quais cobrem parcialmente seus pequenos corpos. Vistas de maneira "autônoma", as imagens indicariam apenas tratar-se de um acidente que as vitimou, mas é no conjunto geral que reconhecemos seu "fluxo imagético", isto é, que constituem parte de uma saga de centenas de milhares de refugiados que arriscam suas vidas ao tentarem uma travessia por mar, em embarcações inseguras.

Sendo assim, ambas as fotografias das crianças sírias mortas no litoral de diferentes países do Mediterrâneo são paradoxais: ao serem divulgadas, ganharam autonomia e repercutiram de diferentes formas em seus receptores. Do mesmo modo, são elementos que compõem um discurso imagético político, complexo, desafiador, que têm diversos outros aspectos em suas composições: os fotógrafos que as produziram, as mídias que as divulgaram, as empresas de comunicação que as financiaram, as dimensões globais que tomaram diante de receptores variados e os domínios ideológicos que constituíram como imagens midiáticas.

Ocorreu nas fotos censuradas o que chamamos anteriormente de "dissenso": elas não estão organizadas de modo a sugerir uma narrativa única, com $o$ intuito de denunciar ou solicitar compaixão dos receptores. Ao contrário: sugerem o que Rancière chama de "arte crítica": "uma arte que sabe que seu efeito político não pode ser garantido, que ele sempre comporta uma parcela de indecidível [sic]" (Rancière, 2012, p. 81). As fotos exploraram as tensões.

Já a imagem de Aylan Kurdi, embora indiscutivelmente triste, atende melhor à expectativa de uma "normalidade", mesmo em situação tão grave como a dos refugiados sírios: o enquadramento, a luz, a distância do corpo em relação à lente da fotógrafa, sua vinculação com a Reuters. Embora Nilüfer Demir tenha explicitado em diversas mensagens que não tinha intenção alguma de produzir uma imagem icônica, o fato é que ela acabou se transformando em uma espécie de "arte engajada". Reproduzida em larga escala nas mídias impressas, pode ter anulado o seu efeito de denúncia e reforçado o "continuum" entre autor e receptor, sem conseguir estimular uma reflexão mais profunda sobre as causas e consequências da crise dos refugiados. 
Note-se, ainda, que a imagem-ícone veio

acompanhada de outras: a da retirada do corpo do

menino por um soldado, configurando uma narrativa com um começo que não se vê (o início da viagem) e seu final (o encontro do corpo por um soldado e sua retirada das águas), como se vê na figura 4, a seguir:

Figura 4: Print screen da capa do portal do The Independent, 02/09/2015, publicada no portal do mesmo jornal na internet.

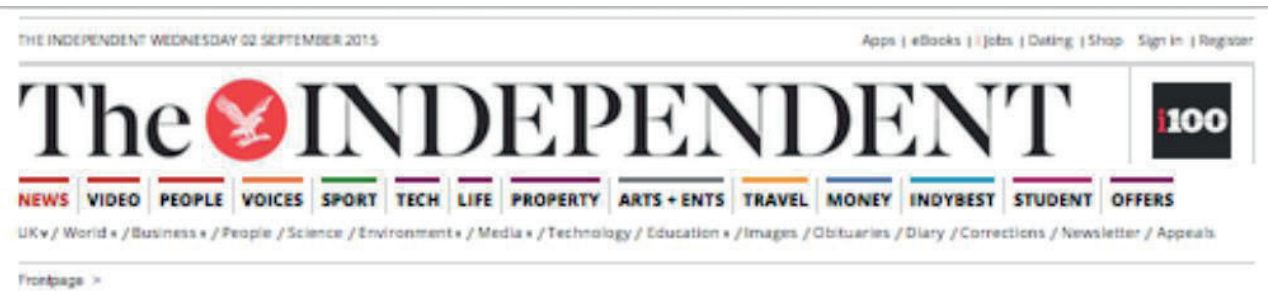

If these extraordinarily powerful images of a dead Syrian child washed up on a beach don't change Europe's attitude to refugees, what will?

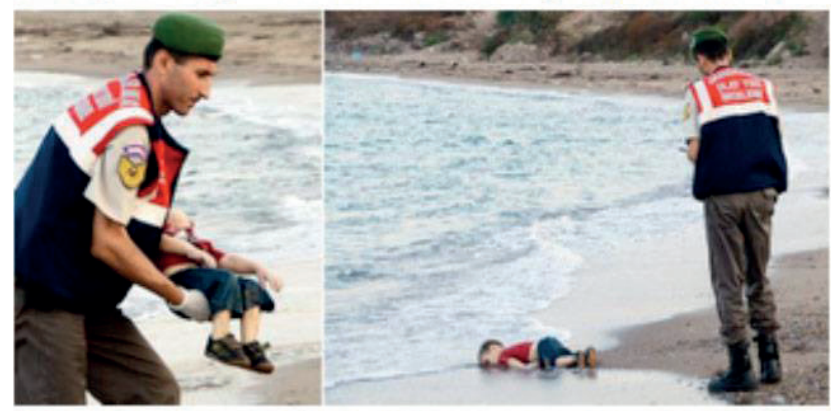

The Independent has taken the dectston to publish the ptetures to serve as a stark reninder of the impact of the retuzee crists. The boy pictured is thoraht to be part of a group of 11 Syrians who drowned off the coastal town of Bodrum in Turkey after an apparent falled attempt to flec the war ravaged country and try to cruss the Soediterramean for the safery of Burope

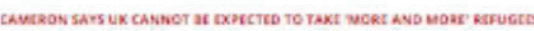

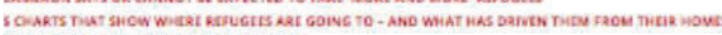

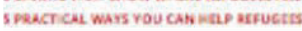

\section{Cameron told: When dead} children are being washed up on beaches, it's time to act

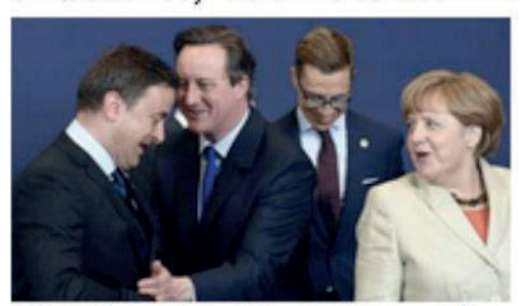

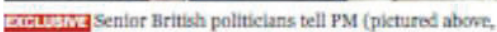
at an $\mathrm{EU}$ summit to consider action agathst human traffickers) the pictures must act as a wake-up call to start sceepting more than just a few hundred refagees froen Syria

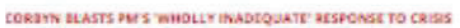

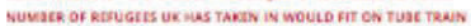

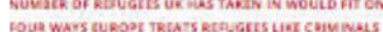

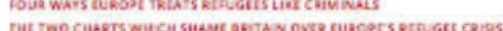
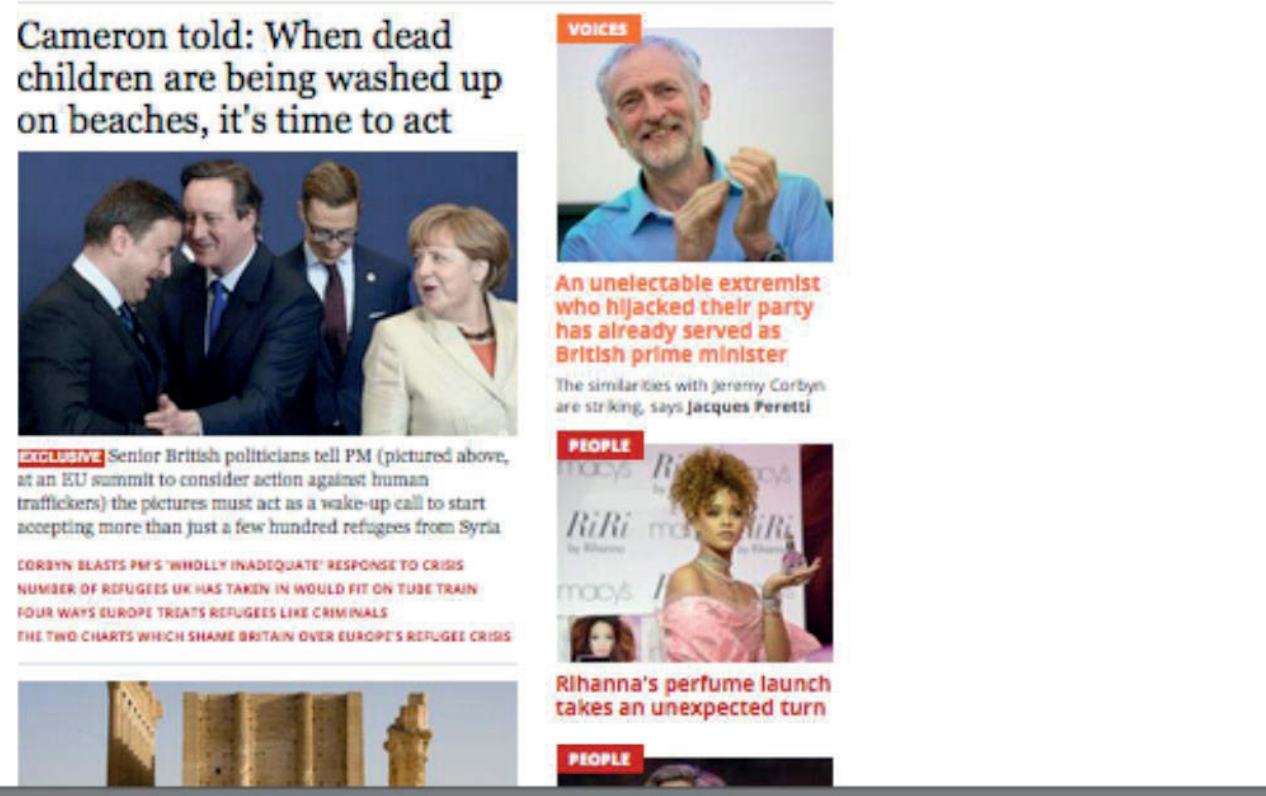
Tomando as manchetes de The Independent, de 02/09/2015, lê-se 0 título extremamente longo, incomum no jornalismo - "Se essas extraordinariamente poderosas imagens de uma criança síria trazida pelas águas para a praia não mudarem a atitude da Europa, o que poderia fazer isso?" - como se fosse uma advertência e não a manchete de uma notícia. Depois vem outra matéria com a foto do primeiro-ministro britânico, David Cameron, e da presidente alemã, Angela Merkel, com a sugestiva chamada: "Cameron disse: quando crianças mortas aparecem nas praias, é hora de agir". Tais frases corroboram a ideia de se tratar de uma mensagem que busca o consenso, isto é, uma reação prevista do receptor. As perguntas, evidentemente retóricas, têm seu impacto diluído pelos títulos ao lado, que tratam de um sequestrador anônimo e da célebre Rihanna e sua marca de perfume. Em outras palavras: as fotos de Aylan Kurdi talvez não sejam "intoleráveis", graças, entre outros fatores, à sua midiatização e banalização.

No entanto, nas imagens das cinco crianças mortas, parece que seus autores não pretenderam "passar uma mensagem" utilizando arte engajada. Ocuparam-se por fazer o registro fotográfico, com uma estética própria, publicaram sem a "anuência" de grandes e hegemônicos meios de comunicação e, assim, as tornaram intoleráveis às condições humanas e políticas.

Tais considerações ajudam a explicar os diferentes tratamentos que 0 Facebook deu às imagens mencionadas.

\section{Mais algumas $\mathbf{e}$ derradeiras considerações}

Susan Sontag, Barbie Zelinger, Jacques Rancière e Roland Barthes, com seus respectivos conceitos, nos levaram à reflexão de possíveis motivos para as imagens das cinco crianças mortas na praia de Zuwara, na costa da Líbia, no norte da África, terem sido censuradas pelo Facebook em um determinado momento. Estas não se transformaram em imagens icônicas e nem mesmo foram toleradas, como ocorreu com as imagens do menino Aylan Kurdi. Nesse sentido, ao invés de serem largamente divulgadas, foram reprimidas, censuradas mesmo, como se deu com o impedimento do Facebook em divulgá-las dias antes de a fotografia do menino correr o mundo digitalmente.

Por sua vez, algumas semanas depois, as mesmas imagens foram postadas na timeline dos autores deste artigo e não foram reprimidas, retiradas nem censuradas. Ressalta-se que a postagem se dera posteriormente à produção da de Alyan Kurdi como imagem-ícone desse episódio que estamos vivenciando na História.

Portanto, o que podemos considerar para terminar, pelo momento, sobre as mídias e a atual crise de refugiados no mundo diz respeito à constituição das imagens intolerantes, da forma como Rancière nos fez pensar. As imagens das cinco crianças mortas representaram, em sua primeira exposição, em 2 de setembro de 2015, o dissenso, o qual rompia com o continuum que os meios de 
comunicação hegemônicos pretendem garantir entre si (emissores) e seus receptores por intermédio de suas mensagens. Receberam um tratamento conotativo bastante desigual, se comparado ao que foi dado à imagem de Aylan Kurdi.

Em seguida, a fotografia da jornalista da Reuters, por ter uma estética mais adequada às formas consensuais de publicar "nossos mortos", pôde ganhar a autonomia da visibilidade e tornar-se, em poucos segundos, a imagem-ícone dessa crise com tristes e atrozes episódios. Aquilo que "parecia" ser, os jornais, nas imagens seguintes, fizeram "aparecer", com a presença do soldado que retira 0 pequeno corpo de Aylan Kurdi das areias molhadas.

Todas essas fotos são desalentadoras, mas 0 que mais nos chama a atenção é a diferença do tratamento estético em cada uma, o que nos permitiu distinguir entre a "imagem intolerável" e a "arte engajada", a que é construída para denunciar um mecanismo de dominação no receptor. Condições provocadoras de dissensos ou consensos entre os meios de comunicação e seus receptores que, do mesmo modo que ainda convivem com o recrudescimento das atrocidades, também convivem com a regeneração de mecanismos de controle e regulação da expressão nos tempos de comunicação digital.

Obviamente, nenhuma das razões aqui levantadas foi percebida pelos "algoritmos neutros" que controlam e vigiam o Facebook. No entanto, tais reflexões nos ajudam a elucidar que em países de regime democrático a censura em redes sociais como o Facebook parece ser praticada não de forma aleatória, mas como estratégia política e também estética.

\section{Referências}

BARTHES, Roland. A câmara clara - Nota sobre a fotografia. Rio de Janeiro: Nova Fronteira, 1984. . A mensagem fotográfica. In: Óbvio e obtuso. (Trad. Lea Novaes). Rio de Janeiro: Nova Fronteira, 1990.

LONGMAN, Gabriela; VIANA, Diego. Entrevista com Jacques Rancière, concedida à Revista Cult, Edição $n^{0}$ 139, setembro de 2009. Disponível em: http://revistacult. uol.com.br/home/2010/03/entrevista-jacques-ranciere/ Acesso: 24 out. 2015.

MARQUES, Ângela. Política da imagem, subjetivação e cenas de dissenso. Discursos fotográficos, Londrina, v.10, n.17, jul./dez. 2014 , pp. 61-86.

MARTINS, Antonio. Censura política no Facebook? CartaCapital, São Paulo, 18/09/2015. Disponível em: http://www.cartacapital.com.br/blogs/outraspalavras/censura-politica-no-facebook-554.html Acesso: 23 out. 2015.

RAMOS, Pedro Hussak van Velthen. Rancière: a política das imagens. Princípios. Revista de Filosofia, Natal (RN), v.19, n.32, jul-dez 2012, pp .95-107. Disponível em: http://revistas.ufrj.br/index.php/eco_pos/article/ view/1279/pdf_28 Acesso: 24 out. 2015.

RANCIÈRE, Jacques. 0 espectador emancipado. (Trad. Ivone Castilho Benedetti.). São Paulo: Martins Fontes, 2012 (a).

. 0 destino das imagens. Rio de Janeiro: Contraponto, 2012 (b).

SONTAG, Susan. Diante da dor dos outros. São Paulo: Companhia das Letras, 2003. 
SOUZA, Vinicius Guedes Pereira de. Deitado à beira mar. Como a foto do menino curdo/sírio na praia turca afetou as pessoas e a política. $\mathbf{V}$ Congresso Internacional de Comunicação e Cultura (V ComCult), Puc/Unip/Cásper Líbero, São Paulo, out. 2015.

ZELIZER, Barbie. About to die - how news images move the public. Oxford: Oxford University Press, 2010. Remembering to forget: holocaust memory through the camera's eye. Chicago: Chicago Press, 1998. 


\begin{tabular}{|c|c|}
\hline $\begin{array}{l}\text { Children of Zuwara: } \\
\text { Facebook's censored images }\end{array}$ & $\begin{array}{l}\text { Los niños de Zuwara: } \\
\text { imágenes censuradas en Facebook }\end{array}$ \\
\hline $\begin{array}{l}\text { Abstract } \\
\text { Images of Syrian refugees were printed in medias, } \\
\text { in September 2015. While Aylan Kurdi's image, who } \\
\text { drowned to death on a beach in Turkey became a } \\
\text { meme, photos of other five dead children, also victims } \\
\text { of the same civil war in Syria, have been censored } \\
\text { by Facebook. The aim of the article is reflecting } \\
\text { about the possibilities that the media images take } \\
\text { as "intolerant image" and image that becomes } \\
\text { "engaged", both for the benefit of contemporary } \\
\text { world policy. It is concluded that the images of the five } \\
\text { children became intolerant as they represent dissent, } \\
\text { which breaks the common sense that the media } \\
\text { aims to ensure between senders and receivers. } \\
\text { Keywords } \\
\text { Censorship. Intolerable image. Facebook. }\end{array}$ & $\begin{array}{l}\text { Resumen } \\
\text { Imágenes de refugiados sirios ocuparon los medios } \\
\text { de comunicación en septiembre de } 2015 \text {. Mientras } \\
\text { que el niño Aylan Kurdi, muerto en una playa en } \\
\text { Turquía, se convirtió en meme, fotos de otros cinco } \\
\text { niños muertos, también víctimas de la guerra civil en } \\
\text { Siria, fueron censurados en Facebook. Se reflexiona } \\
\text { sobre las posibilidades de que las imágenes } \\
\text { mediáticas toman como "imagen intolerable" y } \\
\text { la imagen que se convierte en "comprometida", } \\
\text { ambas al servicio de la política en el mundo } \\
\text { contemporáneo. Llegamos a la conclusión de que las } \\
\text { imágenes de los cinco niños se tornaron intolerables } \\
\text { porque representan el disenso, lo que rompe el } \\
\text { sentido común que los medios están destinados a } \\
\text { proporcionar entre emisores y receptores. } \\
\text { Palabras clave } \\
\text { Censura. Imagen intolerable. Facebook. }\end{array}$ \\
\hline
\end{tabular}




\section{Expediente}

A revista E-Compós é a publicação científica em formato eletrônico da Associação Nacional dos Programas de Pós-Graduação em Comunicação (Compós). Lançada em 2004, tem como principal finalidade difundir a produção acadêmica de pesquisadores da área de Comunicação, inseridos em instituições do Brasil e do exterior.

\section{E-COMPÓS I www.e-compos.org.br I E-ISSN 1808-2599}

Revista da Associação Nacional dos Programas de Pós-Graduação em Comunicação.

Brasília, v.19, n.1, jan./abr. 2016.

A identificação das edições, a partir de 2008, passa a ser volume anual com três números.

Indexada por Latindex I www.latindex.unam.mx

\section{CONSELHO EDITORIAL}

Alexandre Farbiarz, Universidade Federal Fluminense, Brasil Alexandre Rocha da Silva, Universidade Federal do Rio Grande do Sul, Brasil Ana Carolina Damboriarena Escosteguy, Pontifícia Universidade Católica do Rio Grande do Sul, Brasil

Ana Carolina Rocha Pessôa Temer, Universidade Federal de Goiás, Brasil Ana Regina Barros Rego Leal, Universidade Federal do Piaú, Brasil Andrea França, Pontifícia Universidade Católica do Rio de Janeiro, Brasil André Luiz Martins Lemos, Universidade Federal da Bahia, Brasil Antonio Carlos Hohlfeldt, Pontifícia Universidade Católica do Rio Grande do Sul, Brasil

Arthur Ituassu, Pontifícia Universidade Católica do Rio de Janeiro, Brasil Álvaro Larangeira, Universidade Tuiuti do Paraná, Brasil

Ângela Freire Prysthon, Universidade Federal de Pernambuco, Brasil César Geraldo Guimarães, Universidade Federal de Minas Gerais, Brasil Cláudio Novaes Pinto Coelho, Faculdade Cásper Líbero, Brasil Daisi Irmgard Vogel, Universidade Federal de Santa Catarina, Brasil Denize Correa Araujo, Universidade Tuiuti do Paraná, Brasil Eduardo Antonio de Jesus, Pontifícia Universidade Católica de Minas Gerais, Brasil

Daniela Zanetti, Universidade Federal do Espirito Santo, Brasil Eduardo Vicente, Universidade de São Paulo, Brasil Elizabeth Moraes Gonçalves, Universidade Metodista de São Paulo, Brasil Erick Felinto de Oliveira, Universidade do Estado do Rio de Janeiro, Brasil Francisco Elinaldo Teixeira, Universidade Estadual de Campinas, Brasil Francisco Paulo Jamil Almeida Marques, Universidade Federal do Paraná, Brasil

Gabriela Reinaldo, Universidade Federal do Ceará, Brasil Goiamérico Felício Carneiro Santos, Universidade Federal de Goiás, Brasil Gustavo Daudt Fischer, Universidade do Vale do Rio dos Sinos, Brasil Herom Vargas, Universidade Municipal de São Caetano do Sul, Brasil Itania Maria Mota Gomes, Universidade Federal da Bahia, Brasil
Janice Caiafa, Universidade Federal do Rio de Janeiro, Brasil Jiani Adriana Bonin, Universidade do Vale do Rio dos Sinos, Brasil José Afonso da Silva Junior, Universidade Federal de Pernambuco, Brasil José Luiz Aidar Prado, Pontifícia Universidade Católica de São Paulo, Brasil Juçara Gorski Brittes, Universidade Federal de Ouro Preto, Brasil Kati Caetano, Universidade Tuiuti do Paraná, Brasil Lilian Cristina Monteiro França, Universidade Federal de Sergipe, Brasil Liziane Soares Guazina, Universidade de Brasilia, Brasil Luíza Mônica Assis da Silva, Universidade de Caxias do Sul, Brasil Luciana Miranda Costa, Universidade Federal do Pará, Brasil Malena Segura Contrera, Universidade Paulista, Brasil Maria Ogécia Drigo, Universidade de Sorocaba, Brasil Maria Ataide Malcher, Universidade Federal do Pará, Brasil Marcia Tondato, Escola Superior de Propaganda e Marketing, Brasil Marcel Vieira Barreto Silva, Universidade Federal da Paraíba, Brasil Maria Clotilde Perez Rodrigues, Universidade de São Paulo, Brasil Maria das Graças Pinto Coelho, Universidade Federal do Rio Grande do Norte, Brasil

Mauricio Ribeiro da Silva, Universidade Paulista, Brasil

Mauro de Souza Ventura, Universidade Estadual Paulista, Brasil Márcio Souza Gonçalves, Universidade do Estado do Rio de Janeiro, Brasil Micael Maiolino Herschmann, Universidade Federal do Rio de Janeiro, Brasil Mirna Feitoza Pereira, Universidade Federal do Amazonas, Brasil Nísia Martins Rosario, Universidade Federal do Rio Grande do Sul, Brasil Potiguara Mendes Silveira Jr, Universidade Federal de Juiz de Fora, Brasil Regiane Regina Ribeiro, Universidade Federal do Paraná, Brasil Rogério Ferraraz, Universidade Anhembi Morumbi, Brasil Rose Melo Rocha, Escola Superior de Propaganda e Marketing, Brasil Rozinaldo Antonio Miani, Universidade Estadual de Londrina, Brasil Sérgio Luiz Gadini, Universidade Estadual de Ponta Grossa, Brasil Simone Maria Andrade Pereira de Sá, Universidade Federal Fluminense, Brasil Veneza Mayora Ronsini, Universidade Federal de Santa Maria, Brasil Walmir Albuquerque Barbosa, Universidade Federal do Amazonas, Brasil

\section{COMISSÃO EDITORIAL}

Cristiane Freitas Gutfreind, Pontifícia Universidade Católica do Rio Grande do Sul, Brasil Irene Machado, Universidade de São Paulo, Brasil

Eduardo Antonio de Jesus, Universidade Católica de Minas Gerais, Brasil

\section{CONSULTORES AD HOC}

Cleusa M. Andrade Scroferneker, Pontifícia Universidade Católica do Rio Grande do Sul, Brasil Francisco Rüdiger, Pontifícia Universidade Católica do Rio Grande do Sul, Brasil Juliana Freire Gutmann, Universidade Federal da Bahia, Brasil

Karla Regina M. P. Patriota Bronsztein, Universidade Federal de Pernambuco, Brasil Laura Loguercio Cánepa, Universidade Anhembi Morumbi, Brasil Lucia Isaltina C. Leão, Pontifícia Universidade Católica de São Paulo, Brasil

\section{EQUIPE TÉCNICA}

\section{ASSISTENTE EDITORIAL I Márcio Zanetti Negrini}

REVISÃO DE TEXTOS I Press Revisão

EDITORAÇÃO ELETRÔNICA I Roka Estúdio

CONTATO I revistaecompos@gmail.com
COMPÓS I www.compos.org.br

Associação Nacional dos Programas de Pós-Graduação em Comunicação

Presidente

Edson Fernando Dalmonte

Programa de Pós-Graduação em Comunicação

e Cultura Contemporânea - UFBA

edsondalmonte@uol.com.br

Vice-presidente

Cristiane Freitas Gutfreind

Programa de Pós-Graduação em Comunicação Social - PUC-RS cristianefreitas@pucrs.br

Secretário-Geral

Rogério Ferraraz

Programa de Pós-Graduação em Comunicação

Universidade Anhembi Morumbi

rogerioferraraz@anhembimorumbi.edu.br 